удк 338.48

JEL classification: P11, P17, P48, M21, Z32

\section{Тетяна ЗАХАРОВА}

асистент,

кафедра менеджменту зовнішньоекономічної діяльності, готельно-ресторанної справи та туризму,

Вінницький національний аграрний

університет,

Україна

(C) Тетяна Захарова, 2021

Отримано: 21.10.2021 p.

Прорецензовано: 01.11.2021 р.

Рекомендовано до друку: 16.11.2021 р.

Опубліковано: 16.11.2021 p.

\section{(6) 8}

Ця стаття розповсюджується на умовах ліцензії Creative Commons Attribution-NonCommercial 4. 0 , яка дозволяє необмежене повторне використання, розповсюдження та відтворення на будь-якому носії, за умови правильного цитування оригінальної роботи.
Тетяна Захарова (Україна)

\section{ОЦІНКА ЕФЕКТИВНОСТІ ЗАХОДІВ ЩОДО ВДОСКОНАЛЕННЯ УПРАВЛІННЯ ПІДПРИЕМСТВАМИ ТУРИСТИЧНОЇ ГАЛУЗІ В УМОВАХ ЄВРОІНТЕГРАЦIÏ}

\section{АНОТАЦІЯ}

У статті досліджується туристична галузь та можливості ії розвитку. Розглядаються функції, умови та фактори розвитку туризму. Для розв'язання визначених завдань використовувався комплекс методів дослідження, а саме: емпіричні - вивчення та аналіз галузі; спостереження, узагальнення, порівняння. На основі досліджень виявлено проблеми щодо розроблення теоретичних та прикладних досліджень у напрямку формування та розвитку туристичної галузі в Україні. Для кожної окремої країни туризм відіграє істотну роль у стимулюванні економічного розвитку не тільки безпосередньо туристичної галузі, але й суміжних галузей, а також інших галузей економіки. Акцентовано увагу на тому, що туризм позитивно впливає на рівень зайнятості населення, на споживчий попит та рівень валютних надходжень. Роль туризму для розвитку національної економіки важко переоцінити, разом з тим туристична галузь має об'єктивні передумови свого розвитку, що склалися на підставі історичних, географічних, культурних та економічних чинників. Визначено особливості розвитку туристичної галузі, що спрямовано на виявлення можливостей та завад подальшого її розвитку на довгостроковій основі. Матеріали роботи грунтуються на наукових працях провідних вітчизняних і зарубіжних учених, законодавчих актах, нормативних документах. Установлено, що стабільний розвиток туризму можливо на умовах співробітництва держави та бізнесу. Це необхідно для розробки та реалізації програм, які будуть ураховувати специфіку туристичної галузі. Проаналізовано сучасні реалії в Україні та виявлено необхідність створення оптимальних, раціональних та вигідних умов розвитку. Управління туристичною галуззю в Україні в умовах глобалізації та євроінтеграції вимагає пошуку нетрадиційних підходів і нових поглядів, впровадженні європейських норм і стандартів, тобто удосконалення методів управління туристичною галуззю, розробка й оцінка моделей розвитку сфери туризму в системі державного і регіонального економічного розвитку. Для того, щоб прогнозувати ефективність діяльності в статті розглянуто підприємство туристичної галузі, для якого запропоновано використовувати авторегресійних моделі, які допомагають визначити наявність автокореляційної залежності 3 n-лагами запізнення купівельній активності споживачів туристичних послуг.

Захарова Т. Оцінка ефективності заходів щодо вдосконалення управління підприємствами туристичної галузі в умовах євроінтеграції. Економічний аналіз. 2021. Том 31. № 3. С. 133-142.

DOI: https://doi.org/10.35774/econa2021.03.133

Ключові слова: туристична галузь; ефективність; потенціал; авторегресійна модель; політика розвитку туризму; купівельна активність. 
UDC 338.48

JEL classification: P11, P17, P48, M21, $\mathrm{Z32}$

\section{Tetiana ZAHAROVA}

Assistant,

Department of Management of Foreign

Economic Activity, Hotel and Restaurant Business and Tourism,

Vinnytsia National Agrarian University, Ukraine

(C) Tetiana Zaharova, 2021

\section{Received: 21.10.2021}

Revised: 01.11.2021

Accepted: 16.11.2021

Online publication date: 16.11 .2021

\section{cc) (†) 8}

This is an Open Access article, distributed under the terms of the Creative Commons AttributionNonCommercial 4. 0 license, which permits unrestricted re-use, distribution, and reproduction in any medium, provided the original work is properly cited.
Tetiana Zaharova (Ukraine)

\section{EVALUATION OF THE}

EFFECTIVENESS OF MEASURES TO IMPROVE THE MANAGEMENT OF TOURISM ENTERPRISES IN THE CONTEXT OF EUROINTEGRATION

\section{ABSTRACT}

The article explores the tourism industry and the possibility of improving it. The functions, conditions and factors of tourism development are discussed. On the basis of research, problems have been identified in the development of theoretical and applied research in the direction of the formation and development of the tourism industry in Ukraine. For each country, tourism plays a significant role in stimulating economic development, not only directly in the tourism industry, but also in related industries and other sectors of the economy. The impact of tourism on employment, consumer demand and foreign exchange earnings was highlighted. The role of tourism in the development of the national economy cannot be overemphasized, but the tourism industry has objective prerequisites for its development based on historical, geographical, cultural and economic factors. Specific features of the development of the tourism industry have been identified with a view to identifying opportunities and obstacles to its further development on a long-term basis. The materials of the work are based on scientific works of leading domestic and foreign scientists, legislative acts and normative documents.

It has been established that stable development of tourism is possible under conditions of cooperation between the state and business. This is necessary for the design and implementation of programmes that take into account the specificities of the tourism industry. An analysis was made of the current situation in Ukraine and the need to create optimal, rational and advantageous conditions for development was identified. The management of the tourism sector in Ukraine in the context of globalization and Euro-European integration requires the search for non-traditional approaches and new views, the introduction of European norms and standards, that is, the improvement of methods of tourism management, Development and evaluation of models of tourism development in the national and regional economic development system. In order to predict the performance of the activity, the article considers the enterprise of the tourism industry for which it is proposed to use autoregression models, which help to determine the existence of autocorrelation with $\mathrm{n}$-.Delays in purchasing activity of consumers of tourism services.

Zaharova, T. (2021). Evaluation of the effectiveness of measures to improve the management of tourism enterprises in the context of eurointegration. Economic analysis, 31 (3), 133-142.

DOI: https://doi.org/10.35774/econa2021.03.133

Keywords: tourism industry; efficiency; potential; autoregression model; tourism policy; purchasing activity. 


\section{Вступ}

Сучасний етап розвитку економічних відносин у якому глобалізаційні процеси охопили всі сфери світового господарства, охопив у тому числі й туристичну галузь. Туризм - одна 3 небагатьох галузей, яка впродовж довгого періоду часу користувалася неймовірним попитом і тенденцією до зростання. До 2018 року туристична галузь була найперспективніша галузь, так як вона дає можливості творчого та нестандартного мислення. Якщо раніше популярністю користувалися лише визначні пам'ятки певної місцевості, то сьогодні туриста важко ними здивувати. На заміну традиційним формам туристичних подорожей приходять сучасні, нові та неординарні, які дозволяють задовольнити побажання та потреби майже всіх категорій подорожуючих. Але пандемія коронавірусу спричинила глобальну кризу та завдала значної шкоди туристичній галузі.

На тенденції розвитку туристичної індустрії вплинули не тільки прямі обмеження, такі як впровадження карантинних заходів, закриття кордонів, а й опосередковані - заходи, які пов'язані 3 туризмом: ресторанний бізнес, транспортні перевезення, санаторно-лікувальні і медичні послуги тощо. Тобто туристична галузь взаємодіє зв'язку з багатьма елементами, коли негаразди в одному з них можуть суттєво впливати на загальну ефективність.

Залучення до світового туристичного простору України вимагає нових підходів в організації та управлінні туристичним бізнесом. Інтеграція в існуючі міжнародні туристичні процеси та конкуренція на світовому туристичному ринку можливі лише за допомогою використання усіх можливостей країни та регіонів, а також їх ресурсів. Необхідне залучення окремих підприємств різних видів діяльності через ефективне застосування інновацій у галузі туризму, реалізацію основних положень стратегії сталого розвитку та інвестицій. Актуальність дослідження та оцінка ефективності заходів щодо вдосконалення управління підприємствами туристичної галузі наразі посідає одне з перших місць.

Питаннями вдосконалення управління підприємствами туристичної галузі вже впродовж кількох десятиліть перебувають у центрі уваги науковців: Л. Агафонової, В. Азара, В. Безносюка, П. Гамана, М. Біржакова, Є. Богданова, І. Валентюк, Д. Боуена, Р. Браймера, М.Волошина, В. Євдокименка, Т. Кисельова, І. Зоріна, М. Крачила, Р. Ларіна, Дж. Суорбрукера, О. Любіцевої, В. Федорченка, Н. Раскіна, Д. Флетчера, В. Цибуха та iн.

\section{Мета дослідження}

Мета статті- аналіз ефективності заходів щодо вдосконалення управління підприємствами туристичної галузі в умовах євроінтеграції.

\section{Виклад основних результатів дослідження}

Україна в сучасних умовах євроінтеграційного процесу переживає важливий етап у сучасних умовах ринку. Інтеграційні процеси вже сьогодні суттєво впливають на розвиток та розбудову нашої держави. Пришвидшується розвиток науки й освіти, медицини й соціального забезпечення, відбувається загальне технологічне зростання. Входження України в єдиний економічний та політичний простір з ЄС в майбутньому дасть змогу Україні стати потужною європейською державою із сильною армією, розвиненою інфраструктурою центром наукових досягнень тощо.

Європейська інтеграція - це шлях модернізації економіки України, подолання відсталості в залученні технологічних інновацій, гарантія надходження іноземних інвестицій та новітніх технологій, створення нових робочих місць, підвищення конкурентоспроможності підприємств як сфери виробництва, так і сфери послуг, вихід на світові ринки, насамперед на ринок ЄС. Сучасні євроінтеграційні процеси в Україні сприяють інтенсивному розвитку туризму.

У державному бюджеті 2021 рік на туристичну галузь виділено 100 мільйонів гривень. Згідно 3 інформацією опублікованою Укрінформ, Верховна Рада України 15 грудня 2020 року погодила Державний бюджет 2021-го року, у якому передбачила надходження доходів на рівні 1 трлн 92 млрд грн., та видатки 1 трлн 328 млрд грн., а дефіцит бюджету 5,5\% ВВП. Державним бюджетом прогнозовано зростання ВВП на рівні 4,6\%, споживчу інфляцію на рівні 7,3\%, та рівень держборгу щодо ВВП закладено 64,6\%. Середньорічний курс американського долара у 2021 році, згідно якого розрахований державний бюджет, становить 29,1 грн. за 1 долар США [9].

Всім віддомо, що пандемія вплинула на туристичну галузь. Через пандемію коронавірусу У 2020 році туристична галузь України недоотримала приблизно 60 млрд гривень. Дану інформацію повідомила глава Держагентства розвитку туризму України Мар'яна Олеськів під час пресконференції «Оцінка впливу COVID-19 на готельну індустрію України», яка відбулась 20 січня 2021 р. Світові втрати туристичної галузі оцінюються близько 800 млрд доларів, серед яких приблизно 60 млрд грн. - це збитки, які зазнала туристична галузь України у 2020 році. 
За оцінками фахівців та міжнародних організацій криза туристичної галузі поязана 3 пандемією триватиме приблизно до кінця 2023 року. Цю інформацію було озвучено міністром культури та інформаційної політики Олександром Ткаченком в ході виступу на форумі «Україна 30. Коронавірус: виклики та відповіді» [9].

За офіційною статистикою, туризм не посідає значне місце в загальній економіці України, оскільки становить близько 3-4\% від ВВП [9], на відміну від європейських країн, де в середньому на туризм припадає 10\% ВВП, і країн АзійськоТихоокеанського регіону, де ця частка сягає 50,2\% [10]. Хоча, за останніми розрахунками, проведеними внутрішніми експертами міжнародних структур (ВТО, ЮНВТО), частка туризму в Україні становить близько 9\% ВВП [9].
Згідно даних Всесвітньої туристичної організації, приблизно 900 млн. людей щорічно подорожує. Якщо порівнювати ситуацію в Україні з іншими країнами світу, то згідно статистичних даних кількість туристів в середині країни збільшилась, і це $€$ позитивною тенденцією. Враховуючи дану тенденцію та обставини в яких опиналась галузь, терміново необхідно створювати умови для розвитку туристичного бізнесу в середині нашої країни, щоб змогти повністю задовольняти потреби найвибагливіших споживачів. В таких умовах необхідно не тільки мати туристичний потенціал, але також інтенсивно розвивати зовнішньоекономічну діяльність.

Найбільші туроператори України відображено на рисунку 1.

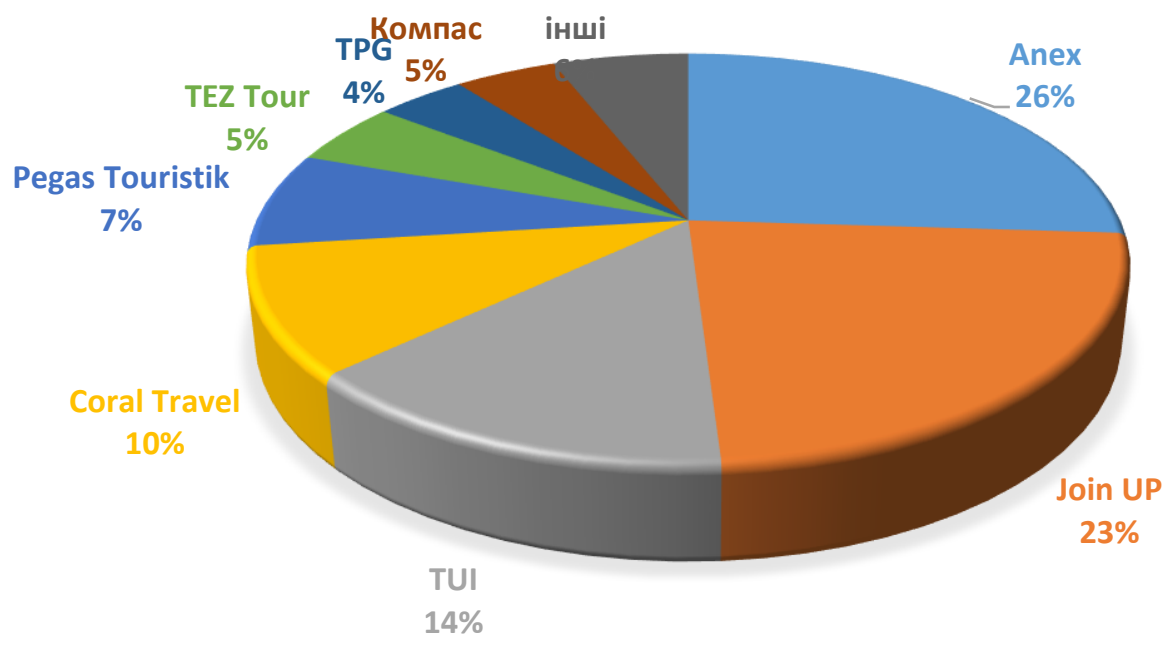

Рис. 1. Розподіл ринку між туроператорами України, 2020 рік

Джерело: сформовано на основі [7].

Зменшення кількості туристів, які відвідують нашу країну призводить до створення негативного сальдо. Переважна більшість українських туроператорів роблять акцент у своїй діяльності на наданні виїзних турів. При цьому у більшості випадків не займаються обслуговуванням іноземних туристів в нашій країні та взаємодією 3 міжнародними туроператорами. Зважаючи на дані обставини кількість людей, що від'їжджають відпочивати за межі країни значно перевищує кількість тих, що відвідують країну. Такий підхід ведення бізнесу в галузі дуже негативно впливає на формування бюджету нашої країни.

Сьогодні, розуміючи ситуацію в країні, туристичним компаніям необхідно розробляти тури відповідно ділового туризму, туризму-події та дослідницького туризму. Тури мають носити характер не тільки як оздоровчо-рекреаційний, екскурсійний а й спортивний, професійноприкладний [8].

у сучасному світі стає популярним вести здоровий спосіб життя. Це створює передумови для розвитку в Україні туристичних компаній, які спрямовуватимуть свою діяльність на оздоровлення клієнтів, поновлення їх працездатності та розвитку фізичної підготовки. Зорієнтувавши свої послуги на спортивний напрямок відпочинку, варто приділити увагу на створення відповідних спеціалізованих занять за видами спорту, проведення спортивних змагань, які 6 використовували природні ресурси. Професійно-прикладний напрямок стане цікавий для людей, які не тільки ставлять за мету відпочинок, але ще й хочуть пізнати щось нове, одержати нові навички та знання у сфері туризму, наприклад, екскурсовода чи інструктора. 
Державне агентство розвитку туризму України провело аналіз даних стосовно перетину українського кордону іноземними громадянами. Згідно оприлюдненої інформації кількість іноземців, що відвідали територію нашої країни, у
2020 році становила 3382097 осіб. Порівнюючи ці дані з 2019 роком, коли Україну відвідало 13709 562 іноземних громадян, зменшення потоку іноземних громадян скоротилося у чотири рази [8].

Таблиця 1. Динаміка туристичних потоків України, осіб

\begin{tabular}{|c|c|c|c|c|c|c|}
\hline \multirow[b]{2}{*}{ Показники } & \multicolumn{5}{|c|}{ Роки } & \multirow{2}{*}{$\begin{array}{l}\text { Відхилення } \\
\text { (+/-) } 2019 \text { р. } \\
\text { до } 2015 \text { р. }\end{array}$} \\
\hline & 2015 & 2016 & 2017 & 2018 & 2019 & \\
\hline $\begin{array}{l}\text { Кількість туристів, } \\
\text { обслугованих } \\
\text { туроператорами та } \\
\text { турагентами, усього }\end{array}$ & 2019576 & 2549606 & 2806426 & 4557447 & 6132097 & 4112521 \\
\hline у тому числі: & & & & & & \\
\hline $\begin{array}{l}\text { в'їзні (іноземні) } \\
\text { туристи }\end{array}$ & 15159 & 35071 & 39605 & 75945 & 86840 & 71681 \\
\hline виїзні туристи & 1647390 & 2060974 & 2289854 & 4024703 & 5524866 & 3877476 \\
\hline Внутрішні туристи & 357027 & 453561 & 476967 & 456799 & 520391 & 163364 \\
\hline
\end{tabular}

Джерело: срормовано за матеріалами [8-9].

Відповідно до отриманих даних (табл. 1) можна зробити висновок, що протягом 2015-2019 рр. кількість туристів, обслуговуваних туроператорами та тураген- тами, зросла на 4,1 млн осіб. Відповідно кількість іноземних туристів, які відвідали Україну збільшилась на 71,7 тис. осіб, а туристів, які виїжджали за кордон - на 3,9 млн осіб. Внутрішні туристичні потоки у 2019 р. зросли на 163,4 тис. осіб порівняно з 2015 р., що свідчить про зростання попиту на внутрішній туризм, як пріоритетної форми туризму.

В 2020 році Україну найбільше відвідувало осіб, що прибули з:

1. Молдови - понад 930 тисяч осіб, показник у 4 рази менший, ніж було у 2019 році;

2. Білорусі - близько 464 тисяч, що в 5 разів менше;

3. Росії - понад 390 тисяч, кількість відвідувачів скоротилась у 5,4 рази;

4. Румунії - 229 тисяч, що у 3 рази менше ніж у 2019 році;
5. Туреччини - 149 тисяч, кількість вдвічі зменшилась.

Згідно офіційної інформації у 2020 році через пункти пропуску державного кордону України сухопутним шляхом прибуло понад два 3 половиною мільйонів людей, морським шляхом понад 122 тисячі осіб, повітряним сполученням приблизно 703 тисячі осіб.

Загальний потік перевезень в аеропортах України у 2020 році склав 8,66 мільйони пасажирів, це у 2,8 рази менше, ніж у 2019 році. Через карантинні обмеження перетину державного кордону, суттєво зменшились міжнародні перельоти. У 2020 році ними скористалися приблизно 7,6 мільйонів людей. $39 \%$ перельотів склали подорожі чартерними літаками. Обсяг усіх перевезень регулярними рейсами у минулому році зменшився у 3,5 рази. Проте, чартерні перевезення скоротилися лише у 2 рази [9].

Таблиця 2. Обсяг пасажирських перевезень в аеропортах України, тис. пасажирів

\begin{tabular}{|c|c|c|c|c|c|c|}
\hline \multirow{3}{*}{$\begin{array}{l}\text { Обсяг } \\
\text { пасажирських } \\
\text { перевезень в } \\
\text { аеропортах } \\
\text { України }\end{array}$} & \multicolumn{2}{|c|}{2018 рік } & \multicolumn{2}{|c|}{2019 рік } & \multicolumn{2}{|c|}{2020 рік } \\
\hline & \multicolumn{2}{|c|}{20545,4} & \multicolumn{2}{|c|}{24334,5} & \multicolumn{2}{|c|}{8664,8} \\
\hline & $\begin{array}{c}\text { Регулярні } \\
\text { рейси }\end{array}$ & $\begin{array}{c}\text { Чартерні } \\
\text { Рейси }\end{array}$ & $\begin{array}{c}\text { Регулярні } \\
\text { рейси }\end{array}$ & $\begin{array}{c}\text { Чартерні } \\
\text { Рейси }\end{array}$ & $\begin{array}{c}\text { Регулярні } \\
\text { рейси }\end{array}$ & $\begin{array}{c}\text { Чартерні } \\
\text { Рейси }\end{array}$ \\
\hline $\begin{array}{l}\text { в т. ч. міжнародні } \\
\text { рейси }\end{array}$ & 13658,7 & 4698,8 & 16530,2 & 5463,9 & 4627,2 & 3001,7 \\
\hline внутрішні & 2152,4 & 35,5 & 2302,8 & 37,6 & 1016,8 & 19,1 \\
\hline
\end{tabular}

Джерело: сформовано за матеріалами [9] . 
www.econa.org.ua

Згідно інформації від АТ «Укрзалізниця», залізничним транспортом міжнародного сполучення в Україні за 2020 рік скористалися майже 17 мільйонів осіб. Ця цифра майже втричі менша у порівнянні з попереднім роком.

Обсяг пасажирських перевезень за 2018-2020 роки відображено діаграмою на рисунку 2.

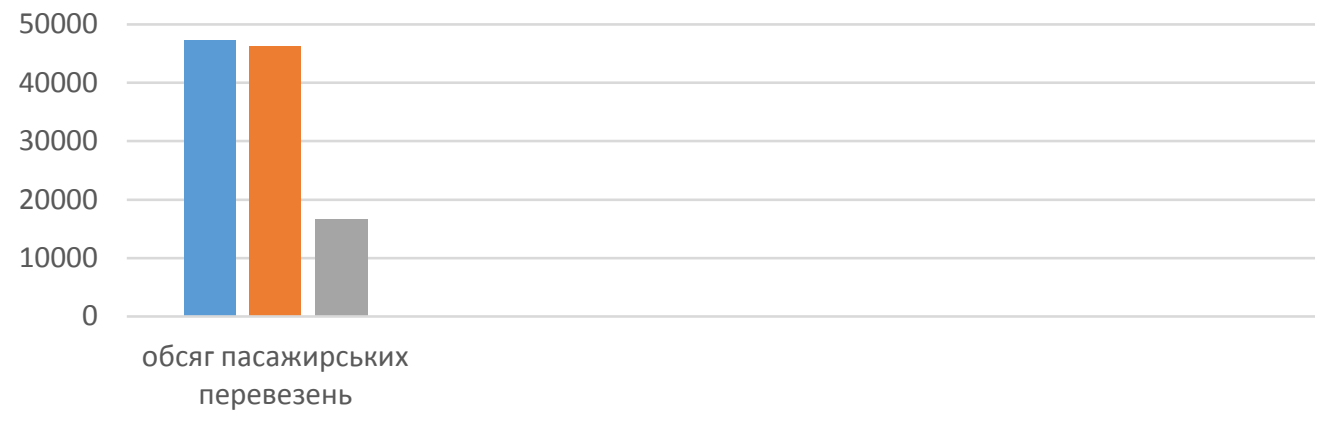

— $2018 \square 2019 \square 2020$

Рис. 2. Обсяг пасажирських перевезень, за інформацією АТ «Укрзалізниця»

Джерело: побудовано за матеріалами [1-6].

В Україні $€$ значний потенціал для розвитку туристичного бізнесу. Сьогоднішній владі та учасникам туристичної галузі України необхідно зрозуміти, що туризм в сучасних умовах може позитивно вплинути на соціально-економічний стан країни, він стимулюватиме надважливі галузі економіки. А результатом цього стане зміцнення позитивного іміджу України [5, с. 74].

До не давного часу ситуація з COVID-19 для українських громадян обмежувала вибір відпочинку за кордоном, що в свою чергу значно збільшувало потік туристів на внутрішньому ринку туристичних послуг. Така ситуація зобов'язувала суб'єктів туристичної галузі посилювати позиції внутрішнього туризму, а саме розвивати в країні тематичний туризм, який передбачає розвиток сільського зеленого, культурно-пізнавального туризму та їх різновидів [2, с. 40].

де $\mathrm{y}_{\mathrm{t}-1}$ - показник у попередньому періоді;

yt - показник у звітному періоді.

Емпіричні значення порівнюються з табличними верхньою $d_{v}$ і нижньою $d_{n}$ межами критерія:

- $d_{p}<d_{n}$ - ряд містить автокореляцію;

- $\quad d_{p}>d_{v}$ - ряд не містить автокореляцію;

- $d_{n}<d_{p}<d_{v} \quad$ - необхідні подальші дослідження.

Усі необхідні розрахунки проведено в Excel (рис. 3).

3 рис. 3 видно, що $d_{p}<d_{n}(0,0051<0,88)$, тому гіпотеза про наявність автокореляції не відхиляється. Далі перевіримо на значущість визначенихданих за критерієм Стьюдента $t_{p}$.

Перевірка гіпотези про наявність автокореляції 3 лагом в один крок, тобто при I=1. Для цього
На даний момент зі зменшенням випадків короновірусу необхідно залучати кошти в рекламну кампанію підприємств туристичного бізнесу як зовнішнього так і внутрішнього туризму. Для того, щоб прогнозувати ефективність діяльності підприємств туристичної галузі потрібно використовувати авторегресійних моделей, які допомогають визначити наявність автокореляційної залежності 3 n-лагами запізнення купівельній активності споживачів туристичних послуг. Для прикладу візьмемо підприємство туристичної галузі ТОВ «ЗАмрий». Для того, щоб визначити та спрогнозувати купівельну спроможність скористаємось критерієм Дарбіна-Уотсона dp [6]:

$$
\mathrm{d}_{\mathrm{p}}=\frac{\sum_{\mathrm{t}=1}^{\mathrm{n}-1}\left(\mathrm{y}_{\mathrm{t}-1}-\mathrm{y}_{\mathrm{t}}\right)^{2}}{\sum_{\mathrm{t}=1}^{\mathrm{n}} \mathrm{y}_{\mathrm{t}}^{2}}
$$

розраховується парний коефіцієнт автокореляції (рис. 4).

3 рис. 4 видно, що $\mathrm{R}_{\mathrm{l}=1}=0,9$. Перевіряємо його статистичну достовірність за допомогою t-критерія Стьюдента [10] (рис.5). Емпіричні значення порівнюються 3 табличними $t_{a} 3$ числом ступенів свободи m=n-l-2 і заданому рівні статистичної достовірності.

Як бачимо, $t_{p}<t_{a}$, тому гіпотеза про наявність автокореляції з лагом в 1 крок не підтвердилася, для цього розраховуємо аналогічно парний

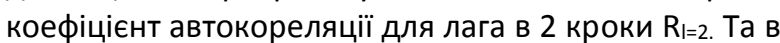
три кроки, щоб визначити 3 якою періодичністю необхідно аналізувати та підраховувати ефективність роботи підприємства. 


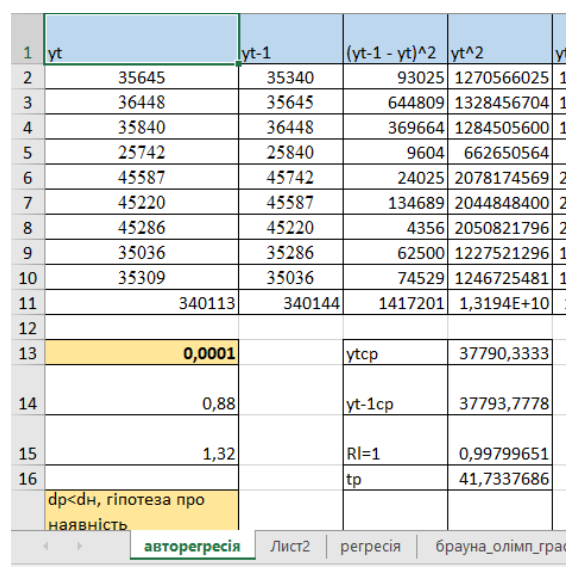

Рис. 3. Розрахунок показників для перевірки гіпотези про наявність автокореляційної залежності Джерело: розраховано автором на основі фінансової звітності

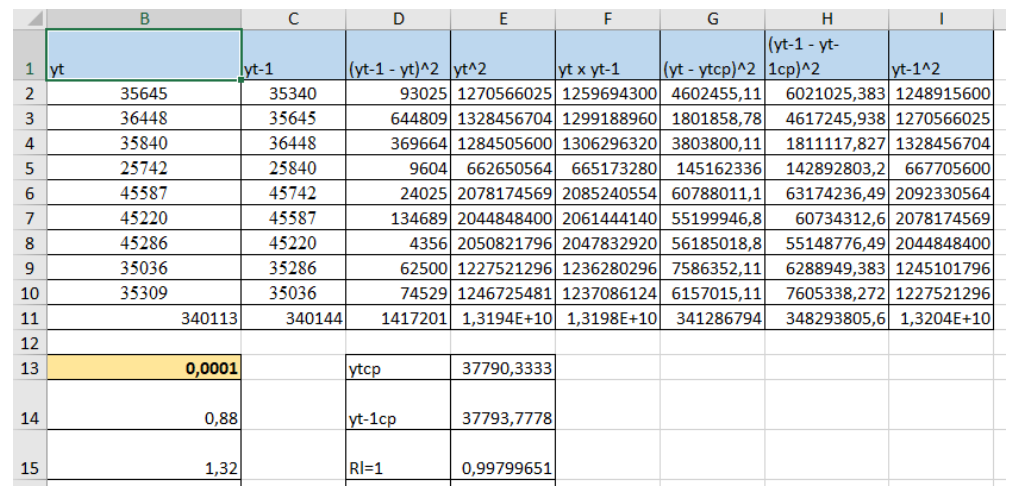

Рис. 4. Розрахунок парного коефіцієнта автокореляції для першого лага

Джерело: розраховано автором на основі фінансової звітності.

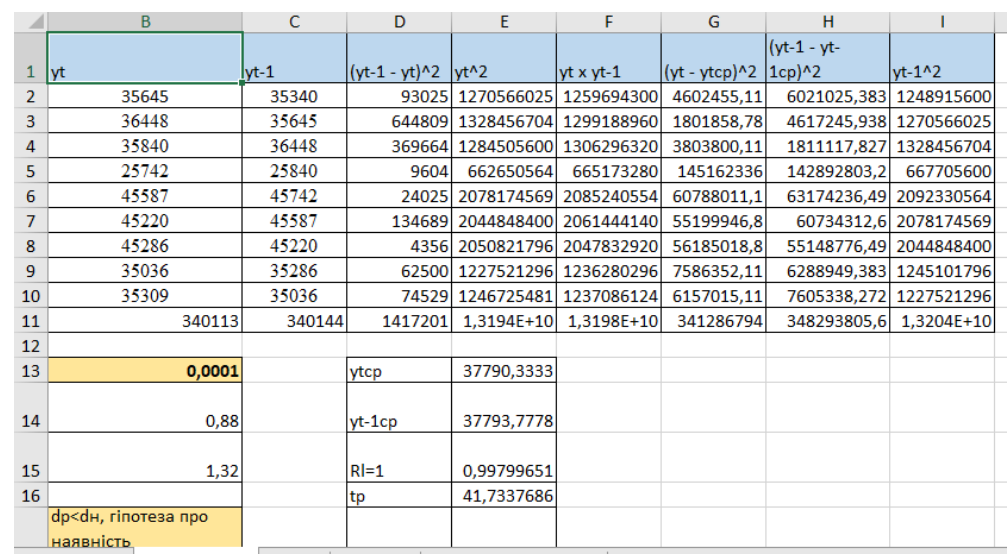

Рис. 5. Розрахунок статистичної достовірності парного коефіцієнта автокореляції з лагом в 1 крок

Джерело: розраховано автором на основі фінансової звітності. 


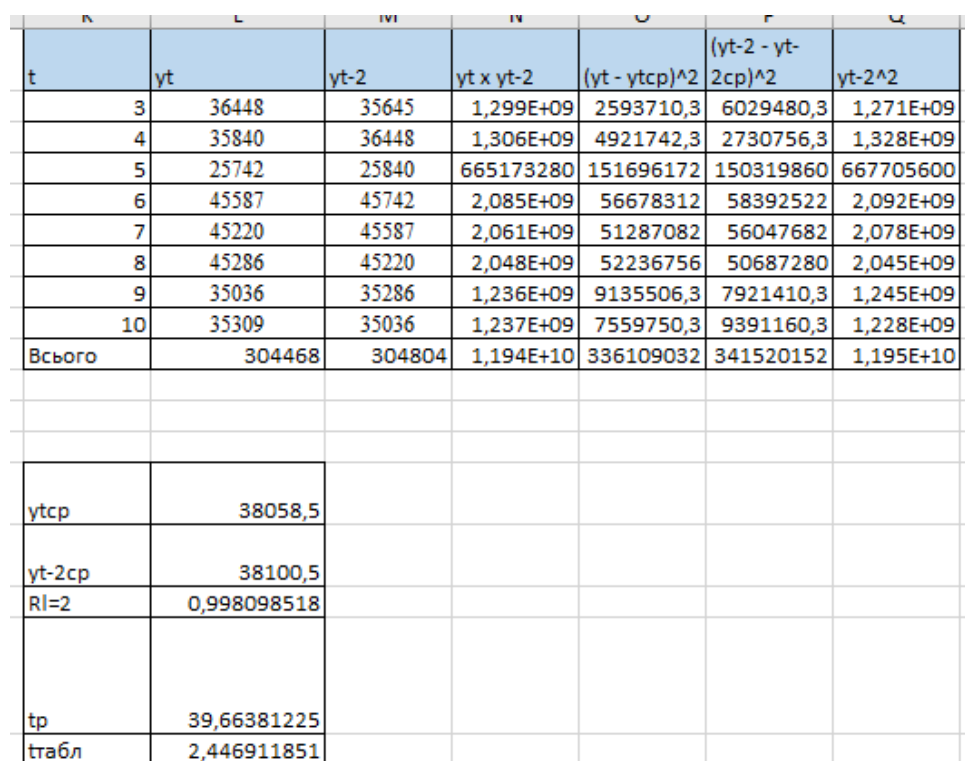

Рис. 6. Розрахунок парного коефіцієнта автокореляції з лагом в 2 кроки і його статистичної достовірності

Джерело: розраховано автором на основі фінансової звітності.

3 рис. 6 видно, що гіпотеза про наявність автокореляції 3 лагом в 3 кроки (3 квартали) підтверджується, тоді необхідно розраховувати 3факторную авторегресійну модель такого вигляду (2) [6]:

$$
\widehat{y_{t}}=a_{0}+a_{1} \times y_{t-1}+a_{2} \times y_{t-2}+a_{3} \times y_{t-3}
$$

Для розрахунку використаємо програму Excel за MHK (рис. 7).

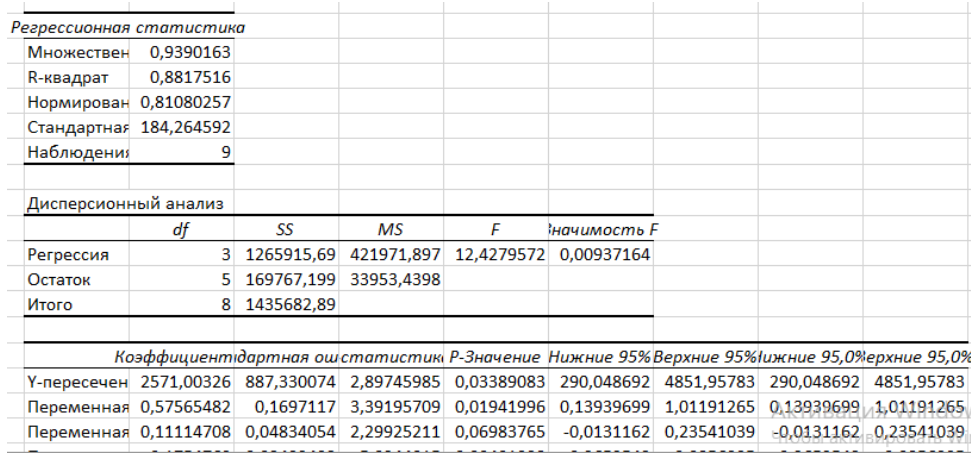

Рис. 7. Розрахунок рівняння авторегресійної моделі для купівельної активності туристичної фірми

Джерело: розраховано автором на основі фінансової звітності.

Рівняння авторегресійної моделі матиме вигляд: $\widehat{y_{t}}=2571+0,511 \times y_{t-3}$

Перевіряємо ії статистичну точність на основі відносної помилки апроксимації $\varepsilon_{v i d n}$, яке повинно становити менше $15 \%$, так як це засвідчує статистичну точність моделі (3) [5, с.74].

$$
\begin{gathered}
\varepsilon_{\text {vidn }}=\left(\sum_{t=3}^{n} \frac{\left|y_{t}-\widehat{y_{t}}\right|}{y_{t}}\right):(n-1) \times 100 \\
=0,1778: 6 \times 100=2,96 .
\end{gathered}
$$

Перевіримо також статистичну достовірність по F-критерію (4) [4]:

$$
\begin{aligned}
& F_{p}=\frac{R_{l=3}^{2}}{1-R_{l=3}^{2}} \times\left(\frac{n-l-m}{m-1}\right) \\
& =\frac{0,75}{1-0,75} \times \frac{10-3-2}{2-1} \\
& =6,27 \\
& F_{a}\left\{\begin{array}{c}
a=0,05 \\
V_{1}=m-1=1 \\
V_{2}=n-l-m=5
\end{array}\right\}=4,06
\end{aligned}
$$

$F_{p}>F_{a}$, тобто, 3 ймовірністю 0,95 можна стверджувати, що рівняння статистично достовірно. На основі даної моделі можна зробити прогнозування купівельної активності за допомогою множинної регресії в Excel. За допомогою використання даної моделі можна визначити як реагує купівельна активність на різні 
фактори, що дає зробити висновки щодо ефективності застосованих заходів на туристичний бізнес. Якщо купівельна активність матиме динамічні показники зростання, тоді можливо дотримуватися проведення такого дослідження кожні 3 квартали, так як нами було виявлено авторегресії в 3 лаги, тобто залежність показників часу між собою, але рекомендується в загальному аналізувати сильні, слабкі сторони, можливості і загрози кожного кварталу.

Отже, можна зробити наступний висновок, що запропонована модель дозволить виявляти періодичність та статистичність прибутку за певний період.

\section{Висновки}

Беручи до уваги місце та роль туризму у житті суспільства, держава повинна визначити як один 3 пріоритетних напрямів у розвитку національної культури та економіки. Україна має значні потенційні можливості для динамічного розвитку туристичної індустрії й відповідної інтеграції у світовий туристичний простір. 3 урахуванням цього уряд повинен сприяти у створенні організаційноправових та економічних засад для розвитку туризму, як високорентабельної галузі економіки, створити передумови для впровадження та застосування міжнародного досвіду.

Зростання купівельної спроможності тільки збільшить частку бізнес-туристів в Україні. Євроінтеграційні процеси, що відбуваються сьогодні, відіграють важливу роль у формуванні нового покоління бізнесменів та політиків, які все частіше беруть участь у міжнародних конгресах i форумах за кордоном не тільки як слухачів, але й як спікери. Розвиток туристичної галузі в Україні за умов глобалізації та євроінтеграції потребує актуалізації видів туристичної діяльності, здійснення інтеграції 3 міжнародними лідерами туристичної галузі, запровадження вже існуючого світового досвіду із задоволення попиту споживачів галузі.

\section{СПИСОК ВИКОРИСТАНИХ ДЖЕРЕЛ}

1. Міністерство інфраструктури України. Євроінтеграція. URL: https://mtu.gov.ua/timeline/ Evrointegraciya.html.

2. Копець Г. Р., Кулиняк І. Я. Сучасні напрями розвитку підприємств у сфері туризму в Україні. Вісник Національного університету "Львівська політехніка». Серія «Проблеми економіки та управління». 2020. Вип. 4. № 2. C.ь37-48.

3. Демків Ю. М., Стукач Т. М. Українська туристична галузь у світовому середовищі: адаптація за умов впливу глобальної міжнародної кризи COVID-19. Бізнес-навігатор. 2020. Вип. 4. C. $18-25$.

4. Transnational corp. URL: orations in the global world economic environment. URL: https://ac.elscdn.com/S187704281631120X/1.

\section{REFERENCES}

1. Ministerstvo infrastruktura Ukrainy. Evroinegraciya. Retrieved from: https://mtu.gov.ua/timeline/ Evrointegraciya.html. [in Ukrainian]
5. Прокопишин-Рашкевич Л. М., Шадурська Б. О., Петрович Й. М. Індустрія туризму в Україні: перспективні напрями та виклики сучасності. Вісник Національного університету "Львівська політехніка». Серія «Проблеми економіки та управління». 2020. T. 4. № 1. C. 72-82.

6. Brussels, Europe's best choice for business tourism. URL: http://www.investinbrussels.com/ en/index.cfm/newsevents/news/brusselseuropee28099s-best-choice-forbusiness-tourism.

7. Про розвиток туристичної галузі України.

URL: http://narodna.pravda.com.ua /travel/5b5f15f4d5bbb.

8. Офіційний сайт Державної служби статистики України. URL: http://www.ukrstat.gov.ua

2. Kopets, H. R., and Kulyniak, I. Ya. (2020). Suchasni napriamy rozvytku pidpryiemstv u sferi turyzmu v Ukraini [Modern Directions of Tourism Enterprises Development in Ukraine]. Visnyk Natsionalnoho universytetu "Lvivska politekhnika». Seriia "Problemy ekonomiky ta upravlinnia», 4(2), 37-48. [in Ukrainian].
9. Офіційний сайт Всесвітньої туристичної організації (UNWTO World Tourism Organization). URL: https://www.unwto.org/news/ 2020-worst-year-in-tourism-historywith-1-billion-fewer-internationalarrivals.

10. Обозна А. О. Аналіз стану розвитку вітчизняної туристичної галузі у відповідності 3 міжнародними рекомендаціями статистичних показників. Ефективно економіка. 2019. № 6. URL: http://www.economy.nayka.co m.ua/?op $=1 \& z=7153$

11. Марченко О. А. Концептуальн засади регіонального розвитку туристичної індустрії. Економіка і суспільство. 2017. № 10. С. 454458

3. Demkiv, Yu. M., and Stukach, T. M (2020). Ukrainska turystychna haluz u svitovomu seredovyshchi: adaptatsiia za umov vplyvu hlobalnoi mizhnarodnoi kryzy COVID-19 [Ukrainian Tourism Industry in the World Environment: Adaptation to the Global International Crisis COVID-19]. Biznes-navihator, 4, 18-25. [in Ukrainian] 
4. Transnational corp. Retrieved from: orations in the global world economic environment. Retrieved from: https://ac.elscdn.com/S187704281631120X/1. [in English].

5. Prokopyshyn-Rashkevych, L. M. Shadurska, B. O., and Petrovych, I. M. (2020). Industriia turyzmu v Ukraini: perspektyvni napriamy ta vyklyky suchasnosti [Tourism Industry in Ukraine: Prospective Directions and Challenges of Modernity]. Visnyk Natsionalnoho universytetu "Lvivska politekhnika». Seriia "Problemy ekonomiky ta upravlinnia», 4(1), 7282. [in Ukrainian].

6. Brussels, Europe's best choice for business tourism. Retrieved from: http://www.investinbrussels.com/ en/index.cfm/newsevents/news/brusselseuropee28099s-best-choice-forbusiness-tourism. [in English]
7. Pro rozvytok turystychnoyi haluzi Ukrayiny [On the development of the tourism industry of Ukraine]. Retrieved

from: http://narodna.pravda.com.u a/travel/5b5f15f4d5bbb/ [in Ukrainian].

8. Ofitsiinyi sait Derzhavnoi sluzhby statystyky Ukrainy [Official site of the State Statistics Service of Ukraine]. Retrieved from: http://www.ukrstat.gov.ua/ [in Ukrainian].

9. Ofitsiynyy sayt Vsesvitn'oyi turystychnoyi orhanizatsiyi [Official site of the World Tourism Organization (UNWTO World Tourism Organization)]. Retrieved from: https://www.unwto.org/news /2020-worst-year-in-tourismhistory-with-1-billion-fewerinternational-arrivals. [in Ukrainian].
10. Oboznaб A. O. (2019). Analiz stanu rozvytku vitchyznyanoyi turystychnoyi haluzi u vidpovidnosti z mizhnarodnymy rekomendatsiyamy statystychnykh pokaznykiv [Analysis of the state of development of the domestic tourism industry in accordance with international recommendations of statistical indicators]. Efektyvna ekonomika - Efficient economy. Vol. 6.. Retrieved from: http://www.economy.nayka.c om.ua/?op=1\&z=7153 [in Ukrainian].

11. Marchenko, O. A. (2017). Kontseptualni zasady rehionalnoho rozvytku turystychnoyi industriyi [Conceptual bases of regional development of the tourist industry]. Ekonomika i suspil'stvo Economy and society, 10, 454-458. [in Ukrainian]. 